Research Article

http://dx.doi.org/10.17784/mtprehabjournal.2014.12.160

\title{
Influence of application of the inelastic taping in plantar pressure of runners pronators.
}

\author{
Influência da aplicação de bandagem rígida na pressão plantar de corredores pronadores.
}

\author{
Juliana Rocha Rodrigues ${ }^{(1)}$, Wesley Albuquerque Craveiro(1), Thiago Vilela Lemos(1), Fábio Alessandro Gal- \\ vão Passos( $^{(2)}$, Osmair Gomes de Macedo(3), João Paulo Chieregato Matheus(4).
}

Ceilândia Faculty, Brasília University, Ceilândia Campus, Brasília (DF), Brazil.

\begin{abstract}
Background: The excessive motion of subtalar pronation of the foot, can cause stress and burden in tissues of the region, giving origin to aches and microtrauma. In clinical practice, excessive movement has been limited to the use of techniques of bandages applied to the plantar arch. Objective: Was to analyze the influence of rigid bandage in plantar pressure distribution corridors pronators. Method: This is a randomized clinical trial, blinded, with twenty runners pronators ( $33 \pm 7 \mathrm{y}, 71 \pm 7 \mathrm{~kg}, 174 \pm 6 \mathrm{~cm}$ ). Technique was applied bandage (rigid - BR) to support the plantar arch, described as antipronation. Plantar pressure data were collected using the $\mathrm{F}$-scan system in three tests run at $9 \mathrm{~km} / \mathrm{h}$ being: no bandages, rigid taping. We considered seven areas of pressure for data analysis, performed by means of ANOVA for repeated measures followed by paired t test. Results: BR resulted in significant reductions $(p<0.05)$ in contact pressures and peak pressure rearfoot. Conclusion: Thus, we conclude that BR provided decrease in contact pressures and peak pressure foot, being significant on the hindfoot than in the midfoot.
\end{abstract}

Key-words: Running, Pronation, Subtalar joint, Foot, Physical Therapy Modalities.

\section{Resumo}

Introdução: No pé, o movimento de pronação subtalar, quando excessivo, pode causar estresse e sobrecarga nos tecidos da região, dando origens a dores e microtraumas. Na prática clínica, o movimento excessivo tem sido limitado com a utilização de técnicas de bandagens, aplicadas sobre o arco plantar. Objetivo: Analisar a influência da bandagem rígida na distribuição da pressão plantar de corredores pronadores. Método: Trata-se de um ensaio clinico, cego,

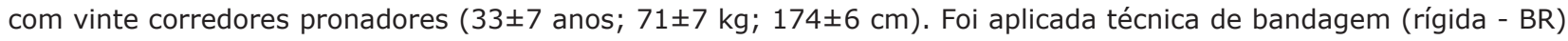
para a sustentação do arco plantar, descritas como antipronadora (low-dye). Os dados da pressão plantar foram coletados utilizando o sistema F-scan em dois testes de corrida a 9 km/h sendo: sem bandagens, com bandagem rígida. Foram consideradas sete áreas de pressão para a análise dos dados, realizada por meio do teste ANOVA para medidas repetidas seguida do teste t pareado. Resultados: A BR proporcionou reduções significativas $(p<0,05)$ em pressões de contato e de pico de pressão no retropé. Conclusão: É possível concluir que a BR proporcionou diminuição em pressões de contato e de pico do pé, sendo significativa sobre o retropé do que no mediopé.

Palavras-chave: Corrida, Pronação, Articulação subtalar, Pé, Modalidades de Fisioterapia.

Received: 14 December 2013. Accepted: 10 March 2014. Published: 30 March 2014.

1. Post Grad student of Science and Tecnology in Science Program, Brasilia University (UnB), Brasilia (DF), Brazil.

2. Orthopedist from Paranoá Regional Hospital and Clínica Cobra, Brasília (DF), Brazil.

3. Physical Therapy, Professor of Physical Therapy School of Ceilandia Faculty (FCE) and Brasilia University (UnB), Brasília (DF), Brazil. 4. Physical Therapy, Professor of Physical Therapy School and guiding of Science and Tecnology in Science Program, Ceilandia Faculty (FCE) and Brasilia University (UnB), Brasília (DF), Brazil. 


\section{INTRODUCTION}

The human foot is the base of support and propulsion for the march, as well as providing support and flexibility for a transfer and support proper weight. $(1,2)$ Proper biomechanics of the foot is responsible for the maintenance of posture and a symmetrical distribution of plantar pressure, and exert an important effect on postural control during upright stance and gait.(3)

During the last decades, the study of human gait has been widely spread among the various centers of sports research.(4) Many studies have been developed with the aim of studying the relationship between physical activity and injury, particularly injuries related to race. $(5,6)$

High plantar pressures may be a causal factor of various diseases and deformities that affect the feet as pain, stress fractures, calluses and neuropathic ulcerations. The analysis of these pressures plays an important role for the proposal to prevent the disorders of the lower extremities, especially the feet. $(7,8)$

The plantar pressure can be measured statically or dynamically, by means of digital baropodometry equipment. In static evaluation, you can determine the kind of foot: neutral, flat or cavus and in dynamic evaluation standards of foot pressure with the ground during the stance phase of gait, from the shock of the heel to the impulsion phase. The dynamic baropodometry can help diagnose podais changes and has been used to investigate the subtalar pronation during gait. ${ }^{(9)}$ In baropodometry, one can observe the intensity of pressure of the midfoot and retrofoot which, in turn, are direct related the movement of pronation and maintenance of the plantar arch. ${ }^{(7)}$

Pronation is a normal component of the stance phase of gait, however, becomes excessive when the hindfoot remains pronated beyond the mid stance phase of gait. ${ }^{(10)}$ This behavior can cause stress and excessive burden on the soft tissues and bony structures, giving origins to cumulative microtrauma and musculoskeletal pain. ${ }^{(11)}$ It is consensus in the literature that excessive subtalar pronation is a major cause of lower limb injuries, especially runners, where this mechanism shall be triggered constantly during the race in order to minimize the harmful effects of the resultant force (normal force) coming from the foot contact with the ground, as well as the excessive internal rotation of the tibia (12). In an attempt to minimize injuries in pronators individuals, clinical physical therapy practice has suggested the use of orthoses able to restrict excess motion of the subtalar joint. Accordingly, the taping have been used to assist in maintaining the medial longitudinal arch and control the amount of pronation. ${ }^{(13,14)}$

The bandage are materials composed of rigid or elastic tapes, ${ }^{(16)}$ applied to the skin, with main objective to promote joint through the mechanical strength of the tape stabilization. ${ }^{(16,17)}$ The inelastic taping has been used to improve the joint positioning, to restrict unwanted movements and preventing pain conditions. ${ }^{(18)}$ previous studies have found a reduction of pronation of the subtalar joint and changes in pressure in the midfoot and retrofoot and forefoot pressures. ${ }^{(19,20)}$

Thus, the aim of this study was to evaluate the influence of the inelastic taping using the low-dye technique in plantar pressure distribution of pronator runners.

\section{METHODS}

This is a randomized clinical trial, cross-over. Conducted in the biomechanics lab and gait analysis of sports consultancy TOP SPORTS, in Brasília (DF). Upon arriving at the research laboratory, the subjects were informed of the procedures and objectives of the research and signed a consent form approved by the Ethics and Human Research, Faculty of Health Sciences, University of Brasilia - Zip/FS UNB - CAAE 11871712.0000.0030, opinion 303,671 .

The study included 20 (twenty) male subjects, mean age $33 \pm 7$ years, mean body mass $71 \pm 7 \mathrm{~kg}$, height média174 $\pm 6 \mathrm{~cm}$.

Were included individuals who had no history of surgery in the lower limbs, who were participating in training for a half marathon races $(21 \mathrm{~km})$ regularly for at least one year, with Body Mass Index (BMI) $\leq 25$, with shoe size 41 and report compatible with subtalar pronation in 1st baropodometric evaluation (Figure 1). Individuals who complained of pain or any sign of injury during testing were excluded from the study.

Data collection was performed by a single researcher in baropodometry equipment brand Tekscan ${ }^{\circledR}$, model F-Scan móbile. The test consists in the use of insoles with pressure sensors of high resolution and coupled to an IBM computer unit transducer system through coaxial cable $150 \mathrm{~cm}$ in length. The insoles have ultrathin thickness $(0.18 \mathrm{~mm})$ and are composed of flexible circuits with approximately 960 pressure sensors distributed over the entire surface (Figure 2).

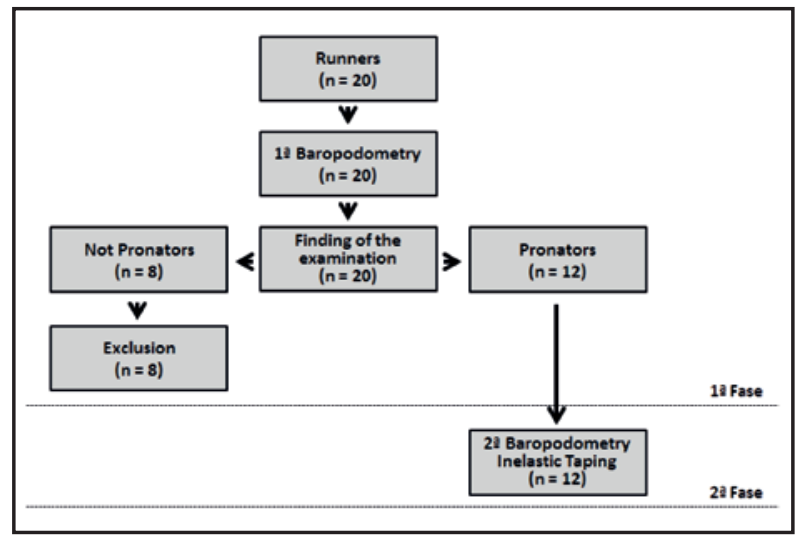

Figure 1. Flowchart and flow of participants. 
In early tests, each volunteer used a new insole, adjusted to the size of shoe used above the original insole. All volunteers wore cotton socks and the same sports shoes during testing being this ASICS $®$ brand, model GEL-ROCKET without support for the foot bar, with fully neutral outsole. The insoles were coupled to the peripheral device socket, which was fixed to the distal end of the leg of the subject by means of Velcro (Figure 3). The axial cables were connected to the top of the socket and then to the athlete's waist by a belt supplied by the manufacturer.

\section{$1^{\text {a }}$ phase}

The tests were performed in two stages. At first, the initial baropodometry evaluation was performed without the application of bandages. For this, the subjects were instructed to sit comfortably in a chair with feet positioned on a flat surface so that all equipment was mounted. After assembly, the subject was sent to start the treadmill equipment calibration performed prior to each exam. The patient was asked to remain in the standing position supporting each foot alternately on the treadmill off. Calibration was made, automatically, taking into account the body mass.

Then, it was requested that the athletes walked on the treadmill with an initial velocity of $0.5 \mathrm{~km} / \mathrm{h}$. This speed was increased gradually, according to report of comfort and safety. After two minutes, on average, reached the speed of the test, $9.0 \mathrm{~km} / \mathrm{h}$ for all athletes. The record of the testing was initiated, without notice to participants and held for 24 seconds, with the capture of 50 frames per second, approximately 1200 images. From these, the software, set the medium of images with the pressures representations. This procedure was performed in 2 phases, in conducting the baropodometrics reviews.

Two professionals with experience in the methodology of the examination, a doctor and a physiotherapist, issued the reports that characterized the volunteer had subtalar pronation during running, the correlation of the two reports should be necessary to be included in the voluntary phase 2 .

\section{$2^{a}$ phase}

Thirty minutes after phase 1 , according to randomization, the application of inelastic taping was only on the foot with greater pronation feature defined in the reports which was performed. The 30 minutes between stages 1 and 2 was established from a pilot study that preceded all tests. In this, care has been taken to ensure that they had no residual effects among baropodometric exams.

Inelastic taping was applied according to standard low-dye taping technique, suitable for midfoot support and correction of pronation ${ }^{(21)}$. Cremer ${ }^{\circledR}$ brand tape, 5 inches wide, placed as follows was used: 1 - the first ta- ping we call anchor, which was applied medial to the first metatarsal, followed by proximal of the first metatarsophalangeal joint and the medial side skirting by the foot and the heel side of the foot, attaching the ribbon at the fifth metatarsophalangeal joint. A longitudinal traction was applied to the tape in order to oppose any forefoot abduction, often a component of pronation. 2 Three applications tapes were then applied to the first anchor of the lateral side of the foot and set the first anchor in the medial border of the foot. A longitudinal traction is applied thereto, so as to oppose pronation. 3 - An anchor was then applied as in (1) to support. 4 - another anchor support was applied contoured metarsos the heads of fixing the anchors (1 and 3) (Figure 4).

\section{Baropodometry}

The contact pressure, which is the force unit divided by the area unit and plantar peak pressure (PP),

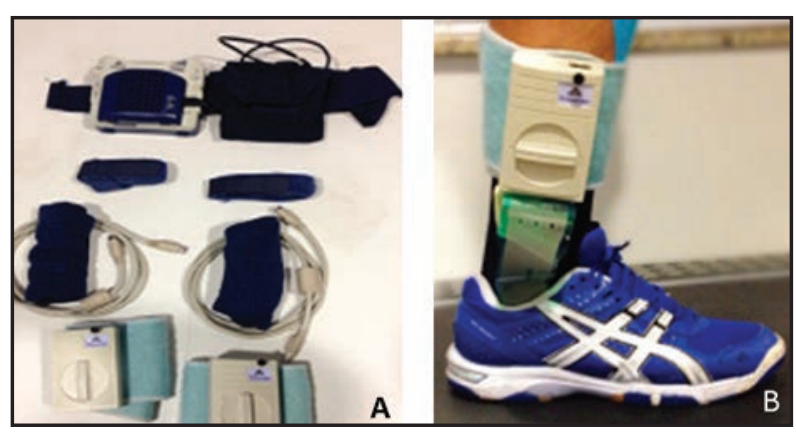

Figure 2. A - complete system of dynamic baropodemetria, B - peripheral system consists baropodometry insole and socket signal capture.

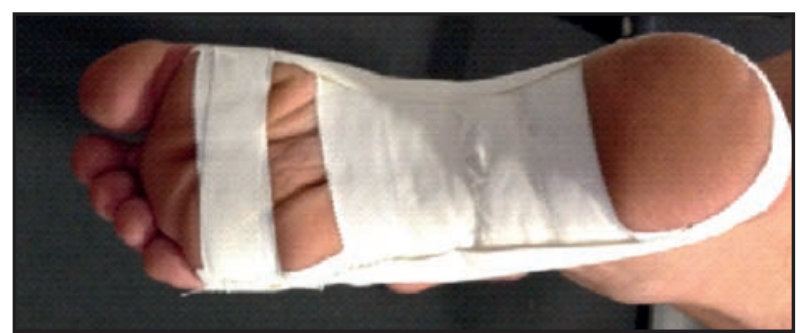

Figure 3. Bandagem rígida aplicada na extremidade do membro inferior - técnica low-dye taping padrão.

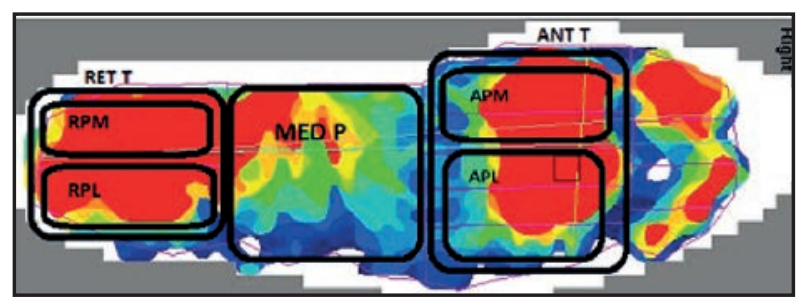

Figure 4. Image recorded by the baropodometry equipment with the distribution of pressures represented by different colors. Subdivision of pressure areas. Medial hindfoot (RPM), Retrofoot Side (RPL), MidFoot (MED F), Total Forefoot (ANT T), Forefoot Medial (APM) and Forefoot Side (APL). 
which is the maximum pressure in the area were the baropodometry parameters analyzed. Both are expressed in kiloPascal ( $\mathrm{kPa})$.

Quantitative analysis (contact pressure and peak pressure) was calculated by dividing the foot into seven parts, medial forefoot (APM), lateral forefoot (APL), total forefoot (APT), midfoot (MED P), medial hindfoot (RPM) , lateral hindfoot (RPL), total rearfoot (RET T), to display changes in plantar pressure distribution. (figure 5).

Statistical analysis was performed using Prism v.4.0, and Graphpad Software. The test of KolmogorovSmirnov test, which confirmed the normality of the distribution was made. For simultaneous analysis of groups, ANOVA for repeated measures was used, and for comparison between groups, the paired test. The significance level for all analyzes was set at $a=0.05$.

\section{RESULTS}

As we can see in Table 1, the means and their standard deviations of the contact pressure in different regions of the foot.

The IT provided $18 \%$ reduction in the contact pressure of the medial hindfoot compared to WB group, this being significant $(p<0.05)$. Also a significant reduction $(p<0.05)$ in the contact pressure of the Retrofoot Side around $17 \%$ compared to the control group (WB).

In total rearfoot, IT provided a $17 \%$ reduction in contact pressure compared to WB, this being significant $(p<0.05)$.

In other comparisons, no significant differences ( $p>0.05)$.

As we can see in Table 2, the means and their standard deviations of peak plantar pressure in different regions of the foot.

IT provided $18 \%$ reduction in peak plantar pressure on medial rearfoot compared to $W B$, this being significant ( $p=0.004)$, IT gave significant reduction ( $p=$ 0.03 ) in peak plantar pressure retrofoot Side around $14 \%$ in the control group (WB).

IT provided a $16 \%$ reduction in peak plantar pressure total rearfoot compared to WB, this being significant $(p<0.05)$.

\section{DISCUSSION}

It was used an equipment baropodometry the Tekscan $\AA$, model F-Scan mobile to review that in addition to already published in other studies, shows good reliability according to the study of Ahroni et al. (22) and Mueller and Strobe ${ }^{(23)}$ was used and can help changes in the diagnosis of feet and has been used to investigate the subtalar pronation during gait( ${ }^{(9)}$ observing the intensity of pressure of the midfoot and retrofoot which, in turn, are directly related to the movement of pronation and maintenance of the plantar arch. (7)

In the pilot study has been defined methodological details, such as running speed, which was kept constant at comfortable position $9 \mathrm{~km} / \mathrm{h}$, this speed enough not to result in muscle fatigue and consequently to changes in behavior pivot relative to the first stage of research. The alternation between the bandagens in the same individual was set to 30 minutes between stages 1 and 2 to ensure that no residual effects were baropodometric between tests. Exclusion criteria was used BMI> 25, because according to Menz and Morris (7) reported that body weight can influence up to $16 \%$ of plantar pressure variables. The excessive weight can cause functional dysfunction of the feet, such as the collapse of the longitudinal arch, which can lead to an increase in the central area counted. ${ }^{(24)}$

As a result of the application of inelastic taping, was obtained decrease in contact pressure and peak plantar pressure in the retrofoot relative to the control group that did not use the bandage application.

The findings of this study are consistent with studies of Lange et al.(25) and Vincenzino et al.(26) also agreed, demonstrating a significant reduction in the contact pressure of the hindfoot after using the inelastic

Table 01. Absolute values of the contact pressure by variable areas. Medial hindfoot (RPM), Retrofoot Side (RPL), MidFoot (MED F), Total Forefoot (ANT T), Forefoot Medial (APM) and Forefoot Side (APL).

\begin{tabular}{|lll}
\hline \multicolumn{2}{l}{ Contact Pressure } & \\
\hline Areas & WB & BR \\
\hline APM & $3294 \pm 1353$ & $3283 \pm 1677$ \\
APL & $4460 \pm 1646$ & $4450 \pm 1631$ \\
ANT T & $7755 \pm 2953$ & $7732 \pm 3232$ \\
MED P & $714 \pm 201$ & $716 \pm 180$ \\
RPM & $2387 \pm 686$ & $1991 \pm 617 *$ \\
RPL & $1713 \pm 583$ & $1436 \pm 494 *$ \\
RET T & $4100 \pm 1216$ & $3427 \pm 1053 *$ \\
$*$ p $<0,05$ compared to control. Without Bandage (WB), Ineleastic Taping \\
(IT).
\end{tabular}

Table 02. Absolute values of the variable peak depression areas. Medial hindfoot (RPM), Retrofoot Side (RPL), MidFoot (MED P), Total Forefoot (ANT T), Forefoot Medial (APM) and Forefoot Side (APL).

\begin{tabular}{lll}
\hline \multicolumn{2}{l}{ Contact Pressure } & \\
\hline Areas & WB & IT \\
\hline APM & $6150 \pm 2595$ & $6394 \pm 3543$ \\
\hline APL & $7522 \pm 2773$ & $7682 \pm 2875$ \\
\hline ANT T & $13672 \pm 5309$ & $14076 \pm 6327$ \\
MED P & $1490 \pm 427$ & $1487 \pm 437$ \\
\hline RPM & $4345 \pm 1514$ & $3597 \pm 1232 *$ \\
RPL & $3719 \pm 1466$ & $3193 \pm 1227 *$ \\
RET T & $8065 \pm 2947$ & $6791 \pm 2408 *$ \\
\hline
\end{tabular}

* $\mathrm{p}<0,05$ compared to control. Without Bandage (WB), Ineleastic Taping (IT) 
taping. They examined the plantar contact area, however, did not evaluate the peak plantar pressure.

Sullivan et al.(27) investigated the efficacy of inelastic taping on low-dye technique in evaluating both plantar pressure distribution (F-Scan) and analyzing the motion of the rearfoot in 3-D. The inelastic taping low-dye resulted in statistically significant increases in peak pressure on average lateral plantar foot, along with a decrease in the lateral medial retrofoot pressure. No significant changes in the medial midfoot ( $p=0.794)$ or forefoot side $(p=0.654)$.

According to the results found in this study, which showed a significant reduction $(p=0.01)$ of the peak pressure in the retrofoot and no significant changes in medial and forefoot. Sullivan et al. (27) also evaluated the 3D motion analysis, which resulted in a statistically significant decrease in retrofoot pronation, supination and retrofoot motion of the total. In conclusion, however, that the application of inelastic taping on low-dye technique appears to reduce both pronation and supination of the retrofoot, rather than simply reducing pronation, when evaluated using analysis of 3D motion. These results have not been reported previously, but is consistent with similar research showing that the addition of foot orthoses resulted in a reduction of the overall movement in the retrofoot, rather than simply reducing pronation. (28) This suggests that it may be inappropriate to mention that the application of inelastic taping with low-dye technique is "anti-pronation" since its effects are not only prone. In a broader context, this is important because the technique is used in up to $73 \%$ of physiotherapists (29) and is commonly described as a technique of "anti-pronation", with less consideration of its effect on supination.
The comparison between different studies that relate the movement of the foot with plantar pressure is limited, since authors use techniques of applying bandages without much description of the method used and the different assessment instruments. ${ }^{(27,30)}$

It was established in the methodology a speed of 9 $\mathrm{km} / \mathrm{h}$, where we observed significant result of the bandages applications, on pronation movement, although new studies were to be conducted using a higher average speed racing to assess whether the bandages also influence the movement of maximum pronation because, according to Turtle et al. ${ }^{(6)}$ found that the maximum subtalar pronation increased significant of $14 \mathrm{~km} . \mathrm{h}-1$ to $16 \mathrm{~km} . \mathrm{h}-1(6.79 \pm 4.01$ degrees to $9.69 \pm 3,14$ degrees) in men, probably showing that the running speed directly influences the behavior of the subtalar joint angle.

\section{CONCLUSION}

We can conclude from this research that the inelastic taping (low-dye taping technique) showed a significant response $(p<0.05)$ in the contact pressure and peak plantar pressure and retrofoot with these results, it can be used in treatment as plantar fasciitis and other diseases that affects the fascia of the foot, requiring more movement limitation for improvement in treatment.

It is important that future similar studies clarify whether the observed changes are larger than the measurement error that the study was unable to do.

Studies will also be conducted to determine the amount of time that the effects of the recording bandages last for a clinical population.

\section{REFERÊNCIAS}

1. Vianna DL, Greve JMD. Relação entre a mobilidade do tornozelo e pé e a magnitude da força vertical de reação do solo. Rev. Bras. Fisioter. 2006; 10(3): 339-345.

2. Orlin MN, Mcpoil TG. Plantar pressure assessment. Phys Ther. 2000; 80: 399-409.

3. Lafond D, Corriveau H, Prince F. Postural control mechanisms during quiet standing in patients with diabetic sensory neuropathy. Diabetes Care 2004; 27: 173-78.

4. Conley DL, Krahenbuhl GS. Running economy and distance running performance of highly trained athletes. Med Sci Sports Exerc. 1980; 12(5):357-360.

5. James SL, Bates BT, Osternig LR. Injuries to runners. Am J Sports Med. 1978; 6(2):40-50.

6. Tartaruga MP, Cadore EL, Alberton CL, Nabiger E, Peyré-Tartaruga LA, Ávila AOV, et al. Comparison of protocols for determining the subtalar joint angle. Acta Ortop Bras. 2010; 18(3):122-6.

7. Menz HB, Morris ME. Clinical determinants of plantar forces and pressures during walking in older people. Gait \& Posture 2006; 24:229-236.

8. Zammit GV, Menz HB, Munteanu SH. Reliability of the TekScan MatScan(R) system for the measurement of plantar forces and pressures during barefoot level walking in healthy adults. Journal of Foot and Ankle Research 2010; 3(11).

9. Lange B, Chipchase L, Evans A. The effect of low dye taping on plantar pressures, during gait, in subjects with navicular drop exceeding 10 mm. J Orthop Sports Phys Ther 2004; 34(4):201-209. 
10. Razeghi M, Batt M. Biomechanical analysis of the effect of orthotic shoe inserts. A review of the literature. Sports Medicine 2000; 29:425-438.

11. Williams DS, McClay IS, Hamill J. Arch structure and injury patterns in runners. Clinical Biomechanics 2001; 16:341-347.

12. Oliveira VM, Detoni GC, Ferreira C, Portela BS, Queiroga MR, Tartaruga MP.

13. Influência do gradiente de inclinação na pronação subtalar em corrida submáxima. Acta Ortop Bras. [online]. 2013; 21(3):163-6. Disponível em URL: http://www.scielo.br/aob.

14. Ator R, Gunn K, McPoil T, Knecht H. The effect of adhesive taping on medial longitudinal arch support before and after exercise. Journal of Orthopaedic and Sports Physical Therapy 1991; 14:18-23.

15. Harradine $P$, Herrington $L$, Wright $R$. The effect of low dye taping upon rear foot motion and position before and after exercise. The Foot 2001; 11:57-60.

16. Chaves MAS, Viana F, Melo PM. Efeito comparativo entre massagem clássica e bandagem funcional no alívio da dor e alteração de tensão da parte ascendente do músculo trapézio. Fisioterapia Brasil 2008; 11(87).

17. Perrin DH. Bandagens funcionais e órteses esportivas. 2. ed. Porto Alegre: Artmed, 2008.

18. Silva JR. Manual de Bandagens Esportivas. $1^{0}$ ed. Rio de Janeiro: Sprint, 1999.

19. Arnheim D. Essentials of athletic training. St. Louis: Mosby Year Book, 1995.

20. Russo S, Chipchase L. The effect of low dye taping on peak plantar pressures of normal feet during gait. Australian Journal of Physiotherapy 2001; 47:239-244.

21. Lange B, Chipchase L, Evans A. The effect of low dye taping on plantar pressures, during gait, in subjects with navicular drop exceeding 10 mm. J Orthop Sports Phys Ther 2004; 34(4):201-209.

22. Vicenzino B, Feilding J, Howard R, Moore R, Smith S. An investigation of the anti-pronation effect of two taping methods after application and exercise. Gait and Posture 1997; 5:1-5.

23. Ahroni JH, Boyko EJ, Forsberg R. Reliability of F-scan in-shoe measurements of plantar pressure. Foot Ankle Int $1998 ; 19(10): 668-673$.

24. Mueller MJ, Strube MJ. Generalizability of in-shoe peak pressure measures using the F-scan system. Clinical Biomechanics $1996 ; 11: 159-164$.

25. Birtane $\mathrm{M}$, Tuna $\mathrm{H}$. The evaluation of plantar pressuredistribution in obese

26. and non-obese adults. Clinical Biomechanics 2004; 19:1055-1059.

27. Lange B, Chipchase L, Evans A. The effect of low dye taping on plantar pressures, during gait, in subjects with navicular drop exceeding 10 mm. J Orthop Sports Phys Ther 2004; 34(4):201-209.

28. Vincenzino B, McPoil TG, Russell T, Peisker S. Anti-pronation tape changes foot posture but not plantar ground contact during gait. The Foot 2006; 16:91-97.

29. O' Sullivan K, Kennedy N, O' Neill E, Ni Mhainin U. The effect of low-dye taping on rearfoot motion and plantar pressure during the stance phase of gait. BMC Musculoskeletal Disorders 2008; 9:111.

30. Eng J, Pierrynowski M. The effect of soft foot orthotics on threedimensional lower-limb kinematics during walking and running. Physical Therapy 1994; 74:836-845.

31. Brown J. Physiotherapists' and podiatrists' views on the effectiveness of treatments for plantar fasciitis. International Journal of Therapy and Rehabilitation 2005; 12:151-157.

32. Norlan D, Kennedy N. Effects of low-dye taping on plantar pressure pre and post exercise: an exploratory study. BMC Musculoskeletal Disorders 2009; 10:40. 